\title{
Breast Abnormalities and Diseases in Adolescents
}

\section{Seema Dayal}

\begin{abstract}
Clinical examination, ultrasonography, and fine-needle aspiration cytology (FNAC) are the diagnostic modalities to diagnose breast lesions in adolescents. But histopathological examination of lumpectomy or biopsy is required to confirm the diagnosis and also the way to management. Inflammatory conditions can be easily managed on medical treatment but awareness and more emphasis should be on the potentially malignant diseases, malignancy, and metastatic breast diseases.
\end{abstract}

Keywords: Adolescent, Breast, Pathology.

How to cite this article: Dayal S. Breast Abnormalities and Diseases in Adolescents. Curr Trends Diagn Treat 2017; 1(2):111-112.

\section{Source of support: Nil}

Conflict of interest: None

\section{Dear Editor}

Adolescents are considered to be people 10 through 19 years of age. ${ }^{1}$ Breast develops in fifth or sixth intrauterine life from ectodermal thickening. ${ }^{2}$ Breast lumps are rare during the childhood and adolescence. Breast disorders in adolescent may occur from development disorders, which include an aplasia or hypoplasia or extra nipple, supernumerary nipples or breast. A wide variety of breast conditions, such as fibroadenoma, phyllodes tumor, virginal hypertrophy, lipoma, hamartoma, cyst, abscess, gynecomastia, and carcinoma can result in solitary or multiple giant masses. Majority of breast diseases in adolescents are benign; malignancies are rare, with reports in the USA being $<0.1$ per 100,000 pediatric cases per annum. ${ }^{3}$

Gynecomastia is a common clinical condition in male adolescents. ${ }^{4}$ It is defined as a benign enlargement of the male breast due to proliferation of the glandular component. Schonfeld ${ }^{5}$ has categorized gynecomastia

\section{Associate Professor}

Department of Pathology, Uttar Pradesh University of Medical Sciences, Saifai, Uttar Pradesh, India

Corresponding Author: Seema Dayal, Associate Professor Department of Pathology, Uttar Pradesh University of Medical Sciences, Saifai, Uttar Pradesh, India, Phone: +919837583969 e-mail: seemadayal5@gmail.com into four distinct groups: simple pubertal gynecomastia, general obesity, gynecomastia, and pectoralis muscle hypertrophy.

Simple pubertal gynecomastia can be managed nonoperatively. Surgery is indicated if the condition fails to regress or if it interferes with social life.

Breast abscess and mastitis may be lactation or nonlactation. Nonlactational mastitis may occur from ductal trauma (e.g., in handling of breasts), mammary duct ectasia, local skin infections, and epidermal cyst. ${ }^{6}$ Upon microscopy examination, lesion shows formation of lipid-filled spaces surrounded by polymorphs, lymphocytes, lipid-laden histiocytes, and foreign bodytype giant cells with foamy cytoplasm. The other causes for mastitis are granulomatous lesions that include mycobacterial, fungal, parasitic infections, sarcoidosis, and idiopathic granulomatous mastitis.

Fat necrosis occurs following physical injury to the breast, such as surgery, needling procedure, radiation, and trauma. The importance lies because it may closely stimulate carcinoma, both clinically and on mammographic examination.

Fibroadenoma is the most common palpable breast lesion in adolescents (Fig. 1). ${ }^{7}$ Juvenile fibroadenoma of breast is defined as circumscribed, often large breast mass occurring in adolescent females with stromal and epithelial hypercellularity (Fig. 2), but lacking the leaflike growth pattern of phyllodes tumor with a mean age of 15 years.

Phyllodes tumor are formed by excessive proliferation of stroma over ductal elements. The proliferative stroma give rises to a leaf-like pattern, also called as "Phyllodes tumor." Microscopy examination shows phyllodes tumor is characterized by stromal hypercellularity and a prominent intracanalicular growth pattern. ${ }^{8}$

Carcinoma of the breast in children is rare. When it occurs, it is usually of secretory type, ${ }^{9}$ although other carcinomas, such as intraductal carcinoma, rhabdomyosarcoma, and lymphoma are also seen. In young patients, metastatic to the breast are more common than are primary breast carcinomas. Metastatic carcinoma of the breast includes Hodgkin's, nonHodgkin's, neuroblastomas, medullary carcinomas of the thyroid, medulloblastoma, hepatocellular carcinoma, and rhabdomyosarcoma. ${ }^{10}$ 


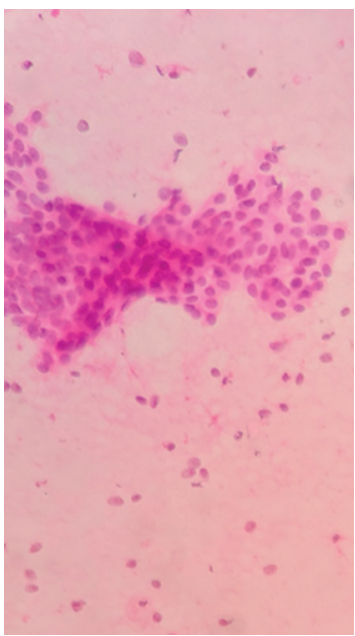

Fig. 1: Fine-needle aspiration cytology, hematoxylin and eosinstained smear of fibroadenoma breast showing sheet of ductal epithelial cells and myoepithelial cells. Naked nuclei are also present in the background

\section{CONCLUSION}

Clinical examination, ultrasonography, and FNAC are the diagnostic modalities to diagnose the breast lesions in adolescents. But histopathological examination of lumpectomy or biopsy is required to confirm the diagnosis and also the way to management. Inflammatory conditions can be easily managed on medical treatment, but awareness and more emphasis should be on the potentially malignant diseases, malignancy, and metastatic breast diseases.

\section{REFERENCES}

1. Centers for Disease Control and Prevention. 21 Critical Health Objective for Adolescents and Young Adults. Atlanta (GA): CDC; 2010 [cited 2012 Mar 31]. Available from: http:/ / www. cdc.gov/healthyyouth/AdolescentHealth/Nationalinitiative/pdf/21objectives.pdf.

2. Moore KL, Persaud TV. The integumentary system. In: Moore KL, Persaud TV, editors. The developing human:

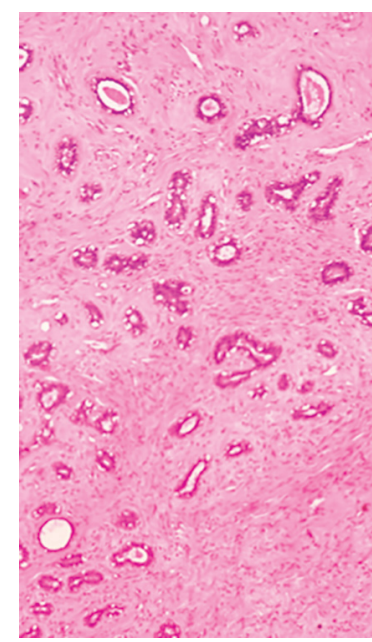

Fig. 2: Hematoxylin and eosin-stained section of juvenile fibroadenoma breast showing epithelial and stromal hyperplasia

clinically oriented embryology. Textbook of embryology. Philadelphia (PA): W.B. Saunders Co; 1998. pp. 513-530.

3. Shannon C, Smith IE. Breast cancer in adolescent and young women. Eur J Cancer 2003 Dec;39(18):2632-2642.

4. Gabra HO, Morabito A, Bianchi A, Bowen J. Gynaecomastia in the adolescent: a surgically relevant condition. Eur J Pediatr Surg 2004 Feb;14(1):3-6.

5. Schonfeld WA. Gynecomastia in adolescence: effects on body image and personality adaptation. Phychosom Med 1962 JulAug;24:379-389.

6. Verma A, Chhatwal J. Common health problems in adolescent In: Parthasarathy A, Nair MKC, Menon PSN, editors. IAP textbook of pediatrics. 3rd ed. New Delhi: Jaypee Brothers Medical Publishers; 2007. p. 946.

7. Mandal AK, Choudhury S. The breast. In: Textbook of pathology. 1st ed. New Delhi: Avichal Publishers; 2010. p. 657.

8. Rosai J. The breast. In: Rosai J, editor. Rosai and Ackerman's textbook of surgical pathology. 9th ed. New Delhi: Elsevier; 2004. pp. 1763-1839.

9. Schnitt SJ, Collins LC. Biopsy interpretation of the breast. 1st ed. Philadelphia (PA): Lippincott Williams \& Wilkins; 2009.

10. Dehner LP, Hill DA, Deschryver K. Pathology of the breast in children, adolescents and young adults. Semin Diagn Pathol 1999 Aug;16(3):235-247. 